\title{
The Foundation for Environmental Conservation: Origin, Objectives, and 1992 Report \& Prospects
}

\author{
AusPiCES AND GOVERNING BOARD
}

$\mathrm{T}$ he Foundation (FEC), which had started operating unofficially some years earlier, was finally established legally in 1975 at Grand-Saconnex, Geneva, Switzerland, as non-profit and tax-exempt* by authority of the Council of State of the Republic and Canton of Geneva and perpetually under Swiss Federal Government surveillance by the Department of the Interior, Berne. Its viewpoint and emphasis are holistically global and its activities as widely international as possible. Its headquarters and Secretariat are at 7 Chemin Taverney ( 7 th \& 8th floors), 1218 Grand-Saconnex, Geneva, Switzerland (telephones [++4122] 7982383 \& 798 2384; fax and another telephone [++4122] 798 2344).

The Founders of FEC were the International Union for Conservation of Nature and Natural Resources ${ }^{*}$ (IUCN), the World Wildlife Fund ${ }^{\S}$ (WWF), both based at Gland, Switzerland, and Professor Dr Nicholas Polunin, of the above address. The Governing Board of the Foundation consists of the last-named for life and a representative each of IUCN and WWF, with powers to co-opt a very limited number of other members for periods of three years at a time (renewable for similar periods).

\section{OBJeCTIVES (UPDATED**)}

A. To undertake, in cooperation with appropriate individuals, organizations, and other groups, all possible activities towards furthering the ends indicated in its title, and specifically:

B. To own and promote pertinent publications, in particular the international quarterly Journal Environmental Conservation, ${ }^{\dagger \dagger}$ and to derive therefrom revenues to be used especially towards coverage of publication costs — in mind are certain other journals, ${ }^{\S \S}$ possible supplements to the present one, and, ultimately, muchneeded works of reference. $\ddagger$ The Foundation-sponsored, open-ended series of Environmental Monographs \& Symposia started publication in 1981, and a complementary series of shorter 'readers', entitled Cambridge Studies in Environmental Policy, started publication in 1990. The 'original paperback' series of Environmental Challenges started publication in 1993.

C. To foster pertinent conferences, in particular the International Conferences on Environmental Future (ICEFs), and to sponsor the Baer-Huxley Memorial Lectures (concerning both of which see below);

D. To organize specialist 'Workshops' etc. to deliberate and pronounce freely on urgent aspects of environmental despoliation or other causes for grave concern, e.g. the widespread dieback of trees and more general devegetation, and the widespread use of good agricultural land for 'development' or other purposes.

E. To encourage, and where possible promote, studies on environmental change, including ecosystem and ecocomplex development and maintenance;

F. To institute through appropriate auspices, and thereafter continue to sponsor and promote, the World Campaign for The Biosphere, 1982 - whose functions were subsequently fostered primarily by the World Council For The Biosphere (see 2 below) and the affiliated International Society for Environmental Education, and are now furthered particularly by Biosphere Day, Fund, Prizes, and Clubs (see below); and

G. To accept and administer (under Swiss Federal surveillance by the Department of the Interior, Berne, and the authority of the Council of State of the Republic and Canton of Geneva) tax-exempt funds for the above purposes, including the creation and bestowal of suitable awards for environmental achievement and allied enterprise. ${ }^{\frac{1+}{*}}$

\section{Projects Past, Present, or Planned}

\section{International Conferences on Environmental Future (ICEFs)}

These are still frequently referred to as noteworthy and needful of continuation to deal with special situations although the fourth, which was held in Budapest, Hungary, in 1990, has always been regarded by the President, their initiator and organizer, as his 'positively last'. It was on the theme of Survival With The Biosphere (see the book of that title published by Edinburgh University Press in 1993). The third ICEF was held in Edinburgh, Scotland, in 1987, and was on Maintenance of The Biosphere (the title of the book similarly published). The second ICEF had been held in Reykjavik, Iceland, in 1977, the book of Proceedings being

\footnotetext{
* Tax exemption further renewed for an undetermined period - see official notification dated 22 March 1993 from the Chief of the Department of Finances and Contributions of the Republic and Canton of Geneva, the wording being 'l'exonération des impôts prévus ... est reconduite pour une durée indéterminée.'

†Now restyled 'The World Conservation Union' but retaining the familiar acronym of IUCN.

$\S$ Now renamed 'The World Wide Fund for Nature' but retaining the familiar acronym of WWF.

** Updated from Environmental Conservation, 16 (1), pp. 75-7, 1989, and 19 (1), pp. 79-80, 1992

i† See the independent assessment of a confidential committee reported in the concluding paragraph on page 98 of this issue.

$\S \S$ Such as a proposed complementary Asian or New World Newsletter.

$¥$ Such as the Index of Titles and Authors in Environmental Conservation, as reported on the following page and further in the opening two paragraphs of the Updated Notice: Publications Available or Forthcoming on page 106, and — far more importantly _- the forthcoming World Who's Who in Environment \& Conservation (see below on pp. 103 and 106).

5 So far we have only the Best Paper Prizes (see the notice on page 98 of this issue and more briefly below on page 105); but we aspire to establish a major Biosphere Prize and several satellite prizes to encourage advances in component sub-fields of endeavour.
} 
entitled Growth Without Ecodisasters? It was published primarily by Macmillan, as had been that emanating from the first ICEF, which had been held in Finland in 1971 as a forerunner to the United Nations' seminal 'Stockholm' conference held a year later. The last three ICEFs have been highlighted by Baer-Huxley Memorial Lectures by outstanding leaders; these should also be continued.

\section{World Council For The Biosphere (WCB)}

This body of 21 Councillors functioned autonomously for some years but as a project of the Foundation, its main purpose being 'to safeguard the continuing integrity of The Biosphere by serving as a select international forum for the analysis and appraisal of existing and foreseeable relationships between human population and economic development on one hand and, on the other, the totality of living and life-supporting systems of our planet which collectively constitute The Biosphere.' So many of its intended functions have latterly been taken on by well-endowed other bodies that, at a meeting in the Foundation's Headquarters on 24 October 1992, it was decided that WCB's remaining activities should revert directly to FEC. Meanwhile 'WCB should cease separate functioning, pending reconstitution as a rejuvenated body with its own administration, budget, and duly revised Constitution'**

\section{Environmental Conservation and its Index etc.}

The Foundation's quarterly Journal has long-continued its influential way with an abundance of worthy submissions sent gratuitously from practically all over the world. Besides the usually 7 or 8 refereed and mainly scientific papers constituting its core, each issue contains 5 regular sections of normally from 4 to 10 pages each, namely (1) Editorial, etc.; (2) Short Communications \& Reports; (3) Notes, News \& Comments; (4) Conferences \& Meetings; and (5) Book Reviews \& Notices. Funds are still sought (a) to help with more editorial and incidental expenses, and (b) to increase the value of the annual Best Paper Prize which the Foundation's confidential Awards Committee almost habitually requests be split four ways.

The cumulative 'Index of Titles and Authors in Environmental Conservation, 1974-86', comprising 159 pages in the format of the Journal, is still available from the Foundation's Secretariat (address below) at the price of US \$35 or SF 50 (postage included). It was followed by a Supplement covering the years 1987 and 1988 , which is sent free to all recorded purchasers of the original Index while stocks last, and thereafter by 5yearly supplements of which the first is due out in 1994 and will likewise be sent free to all recorded or new purchasers of the Index.

\section{Other Journals and Series of Books}

(a) Means are desired to encourage and help worthy journals through sponsorships, memberships, or serving on boards, an example being Environmental Awareness, the organ of the International (formerly Indian) Society of Naturalists (INSONA), of which the President and his Wife are Patrons, he being now a Vice-president. Other instances include resurrection of The Biosphere and the Bulletin of the Asian Society for Environmental Protection, of which the President is a Life Member.

(b) Environmental Monographs \& Symposia: Means are desired to support special cases with a leading international Publisher, and to help (c) the complementary Cambridge Studies in Environmental Policy series (likewise sponsored by the Foundation), to consist of highly authoritative 'readers' for environmental policymakers, politicians, and the enlightened public. Of its Editorial Board of the Cambridge University Press the President is Chairman.

(d) Original Paperback 'Readers by Leaders': Of these the first, entitled Environmental Challenges: From Stockholm to Rio and Beyond, with a Foreword by Norway's Prime Minister, Gro Harlem Brundtland, and chapters by Mostafa K. Tolba, Nafis Sadik, Arthur H. Westing, Maurice F. Strong and a co-Author, and other leaders in the field, has recently been printed. The Foundation is being presented with 1,000 copies to distribute for US \$12 apiece to individuals or US \$20 to institutions. If this Original Paperback proves financially viable it will be followed by others, for which more than 30 possibilities have already been collected and one, on the theme of Population and Global Security, has already been planned and committed to - see item 5 in the Updated Notice on page 106 of this issue.

\section{World Education Concerning The Biosphere}

With the object of promoting world-wide knowledge of The Biosphere and appreciation of how humans are an integral part of it and utterly dependent on it, and yet are threatening it with their ever-increasing numbers and pressures on its finite resources, there were proposed in Environmental Conservation successively various activities and bodies leading up to the joint World Council For The Biosphere (WCB)-International Society for Environmental Education (ISEE). The former of these was founded primarily to foster the World Campaign for The Biosphere, while the latter became most closely associated with the North American Association for Environmental Education (NAAEE), of which the President is a Life Member. WCB was subsequently

* See 'Notice: WCB and FEC', Environmental Conservation, 19(4), p. 296, 1992. However, as we go to press it looks as though the International Green Cross, recently founded under the Presidency of Mikhael Sergeyevich Gorbachev and planned to operate from Geneva and The Hague, may well be taking over the last-remaining major intended function of WCB, namely approaching decision-makers and influencing governments regarding impending dangers or ameliorative chances. 
strengthened with the election of a full complement of 21 Councillors plus the Secretary-General of ISEE and a distinguished Media Adviser, the agreed adoption of a binding Constitution, and the appointment of a Secretary-General. Latterly, however, WCB has had several of its main raisons d'etre taken on by other bodies and its aspirations undermined otherwise; so it has been suspended as an active body in the manner explained in 2 above and footnote* on the preceding page. Of its residual functions that have reverted directly to FEC, the item following next should be especially noted - also that the affiliated ISEE looks like being superseded by a new body to collate Environmental Education world-wide which was founded during the United Nations Conference on Environment and Development (UNCED), held at Rio de Janeiro in June 1992. ${ }^{\dagger}$

\section{Biosphere Day, Fund, Prizes, and Clubs}

The Biosphere is that favoured layer of our Planet Earth's periphery - solid, liquid, and gaseous — in which any form of life exists naturally. It extends as far up into the atmosphere and down underground as any form of life persists without artificial aid, and so constitutes our entire human and all other known forms of life's sole natural habitat. It is therefore our utmost human, surely quintessential, duty to look after The Biosphere in every possible way. For this perhaps 30-km-thick peripheral layer of our Planet is relatively transient and alltoo-fragile, being gravely threatened by human population-pressures and profligacy; yet few seem to understand the true situation. Consequently we proposed, on 21 September 1991, that the same day on the calendar annually henceforth be solemnly observed and duly celebrated by all humanity as Biosphere Day. This follows Earth Day in early Spring and Environment Day normally on June 5th, and heralds in the Autumn Equinox in the Northern Hemisphere and reciprocally the Spring Equinox in the Southern Hemisphere.* To foster Biosphere Day we have proposed a supporting Fund and Prizes — the latter hopefully comprising one major Biosphere Prize and about 6 satellite prizes for advances in component parts of the subject - and also Biosphere Clubs which it is hoped will ultimately span the world.**

\section{Research and Writing etc. Projects}

(a) Various worthy research and survey projects have been encouraged with due publication of their results, but a budgetary item to help future ones financially with at least seed money would be warmly welcomed and surely put to good use. ${ }^{\dagger \dagger}$ Attractive possibilities keep coming to mind, and rarely does a month pass without at least one worthy proposal being conceived or received in application form to our very small and almost unendowed Foundation.

(b) Among writing and editing projects, in addition to the books' series mentioned above in 4 (b), (c), and (d), and the books of Proceedings etc. emanating from each of the four ICEFs cited in l, we have a new edition of the President's Introduction to Plant Geography and Some Related Sciences being undertaken in collaboration with the Senior Lecturer in Plant Geography and Soil Science in the University of Hong Kong. The new edition should include additional sections or at least passages on pollution effects and ecology, plant conservation, introductions and their effects, plant competition, continental drift, foreseeable effects of climatic change, and the role of plants in environmental conservation - for all of which, and widespread updating, specialist cooperation will be needed. An Indonesian edition of Ecosystem Theory and Application is under way for which a useful cheque has been received on behalf of FEC. Meanwhile the following three attractive prospects have been approved by the Foundation and are under active consideration:

(c) a planned anthology on the theme of Environmental Education Around the World, which it is hoped will be edited by two acknowledged leaders in the field;

(d) a book on The Imperative of Expert Environmental Impact Assessment Before Funding (ditto); and

(e) A History of Europe's Forests, at the instance of a trained forester who recently retired from long service in a uniquely pertinent position.

\section{World Who's Who in Environment \& Conservation}

With the subtitle of Leading Specialists, Administrators, and Benefactors, it has now been finally decided to complete this much-needed compilation over the next few years and to publish it by some means as yet undetermined. The expectation is to have about 3,000 biographies in a handy volume of some 600-700 pages, and the hope is to find a benevolent donor who will enable us to send a gift copy to each and every published biographee. Nearly four thousand copies of the Questionnaire have so far been printed and are being sent to a like number of potential biographees who have been chosen with the help particularly of The World Conservation Union (IUCN) and the United Nations Environment Programme (UNEP) as well as from the Foundation's files and have subsequently been approved by its confidential Awards Committee which makes the final choices of those to be sent the Questionnaire and, with it, a sheet of sample biographies in the style and format of the planned volume of which a dummy has been provided by the Foundation's Printer.

\footnotetext{
'See pages $90-91$ of our preceding issue (20[1], 1993).

* See 'Biosphere Day', Environmental Conservation, 19(3), p. 194, Autumn 1992.

$\$$ 'Biosphere Day and Its Needed Fund and Prizes’, ibid., p. 193.

** 'Introducing Biosphere Clubs', idem, 20(1), p. 3, Spring 1993.

${ }^{\dagger}$ Here we cannot help thinking of our Editorial in the current issue (Environmental Conservation, 20[2], p. 97, 1993).
} 


\section{FURTHER DESIDERATA ${ }^{\S}$}

(a) 'Feasibility study of a proposed top-level World Academy of Environmentalists': Shelved in hopes that the International Academy of The Environment, established early in 1991 at Conches, Geneva, Switzerland, will in time prove to be just that.

(b) 'Compilation of a long-planned World Who's Who in Environment \& Conservation ...' dealt with in 8 above.

(c) "Encouragement of a proposed "World Circle for Survival Concensus" to support the World Council For The Biosphere in its efforts towards impressing on decision-makers and the world at large the imperative of action along appropriate lines ... to relieve increasing pressures on The Biosphere'. This is not now being activated as WCB is ceasing separate functioning for the time being ( $c f .2$ above) and, as regards any 'salvation' aspects, is likely to be taken care of by the International Green Cross activities in Geneva and The Hague (under the Presidency of Mikhail S. Gorbachev, of Russia, see the footnote on page 102).

(d) Endowment is desired of the Baer-Huxley Memorial Lectures on topics of contemporary environmental concern, normally given in connection with ICEFs - see I (above). Previous Lecturers have been Maurice F. Strong, Gro Harlem Brundtland, and Mostafa K. Tolba.

(e) Endowment of the Foundation's annual Best Paper Prize which hitherto has been bestowed on up to 9 people at once and so become undesirably subdivided. Most often to date each year four papers (commonly of multiple authorship) have been chosen as joint winners, which seems a useful indication of the general quality of papers published by the Foundation.

(f) In view of the quadrupling in value of the International Sasakawa Environment Prize, the establishment of the Blue Planet Prize of two even-more-valuable halves, and the expectation that the Nobel Peace Prize may soon be considered as embracing environmental peace, it seems that the need for annual awards for environmental attainment and leadership is at last being taken care of, and that we should now concentrate on more specific Biosphere Prizes as indicated in 6 above.

(g) The convening of 'working groups of leading specialists to pronounce quite freely on major environmental threats' seems likely to be effected through the Geneva and The Hague 'International Green Cross' plans and/or the International Academy of The Environment.

(h) Sponsorship without financial commitment of appropriate conferences such as the projected series of International Conferences on Waste Minimization and Clean Technology and the desirable two-yearly Geneva Congresses on Recycling and Resource Economy with the Recycling Trade-fair.

(i) For effective perfection of Dr Robert G. Bailey's map of the Ecoregions of the Continents, published as a supplement to Environmental Conservation in 1989, collaboration over the 4-years' period 1992-5 has been arranged with Professor Vladimir N. Bashkin, of the Vernadsky International Centre for Biosphere Studies and the Institute of Soil Science and Photosynthesis, Russian Academy of Sciences, as part of the overall study of Human-caused Soil-ecological Changes and Their Effect on The Biosphere, proposed by the late Professor Victor A. Kovda, co-Founder of the Vernadsky International Centre with the President.

(j) Research projects in mind include investigation of possibilities of recovery of trees and shrubs from damage due to acidic precipitation and/or other pollutional effects.

(k) Further desiderata include fostering the establishment of associated foundations in other parts of the world (such as one for Environmental Awareness in Baroda, India) in the belief that small outfits can often operate more effectively than large ones - relatively to their size or sometimes even absolutely!

(1) Under consideration is an invitation to cooperate with ProWorld, Maputo, Mozambique, in planning a 5years' project on 'The Economic and Social Pressures for a Sustainable Management of Energy and Environment in Mozambique', with our associates who include the Founder and President of a national Energy and Environment Society and the Chairman of a world energy concern of which the Headquarters is soon moving to Geneva. ${ }^{\dagger}$ Also under consideration are overtures concerning ecologically-sound plans for Nepal and representation on the Advisory Board of a major reforestation project for Pakistan.**

\section{PRESIDENT'S 1992 REPORT \& PROSPECTS}

Most recent advances having been reported already in the above updated account of the Foundation's origin and main objectives, it remains for us here merely to report the specific events or changes that occurred during the year AD 1992. These, following the sequence in our latest 'President's Report for the Year 1991', and published as requested in Environmental Conservation (Vol. 19, $\mathrm{Nr} 1$, pp. 79-80, Spring 1992), are as follows:

\footnotetext{
$\$$ With some additional projects and proposals but following in sequence the items (a)-(i) under this heading in the latest preceding published account of FEC (in Environmental Conservation, 17[2], pp. 175-7, 1990).

* See 'Background statement of global project: Human-caused soil-ecological changes and their effect on The Biosphere', by Vera A. Dmitrieva, Victor A. Kovda, Nicholas Polunin \& Yakob A. Pachebsky, Environmental Conservation, 18(3), p. 197, Autumn 1991; also 'Revision of map of ecoregions of the world', by Vladimir N. Bashkin \& Robert G. Bailey, idem, 20(1), pp. 75-6, 1993. It is hoped soon to arrange for the participation of another appropriate world body in this major project.

${ }^{\dagger}$ See Professor Peter J. Catania's note: 'International Energy Foundation (IEF) Headquarters Move to Geneva', published on page ??? of this issue.

** And, as we go to press, a request to 'co-sponsor, without any financial commitment', a 'Ist International Scientist and Technologist Congress \& Convention' late this year in seemingly all the main hotels of Singapore.
} 
1) Environmental Conservation:- This past year again it has seemed to us that we continue to be sent, unsolicited from practically all over the world, a gratifyingly large proportion of the most pertinent environmental and conservational writings from which to choose the quarterly issues of our Journal that, in its nineteenth year and volume of publication since we relinquished Biological Conservation, has involved 19 items in the Editorial section, 29 'main' Papers, 15 Short Communications \& Reports, 33 Notes, News \& Comments, 24 Reports of Conferences \& Meetings with, terminating the same section, 11 Notices of Important Prospects, and 22 Book Reviews and 2 Notices, in addition to 'cover' materials and the annual list of Other Books etc. Received during 1991. Thus in our nineteenth volume were published 156 separately-headed items, a large proportion of them with illustrations \&/or tables. But although this is a small drop from the 164 of the preceding year, there has been a further increase in the number of requests for reprinting permissions. These are usually granted free-of-charge provided the purpose is worthy, but with a counter-request for some royalty consideration for FEC for at all substantial items that are to be in works for widespread sale.

2) International Conferences on Environmental Future:- The publication this year of the book of Proceedings of the Fourth of this series terminates the President's involvement as organizer etc. - see 1 under the heading of Projects ... .

3) World Council For The Biosphere:- See 2 under the heading of ProJeCTS ... .

4) Environmental Monographs \& Symposia and Cambridge Studies in Environmental Policy:- From the former series with John Wiley \& Sons, arrangements have been completed for an Indonesian edition of the President's Ecosystem Theory and Application, and in the latter series, with Cambridge University Press, a paperback edition of Professor Lynton K. Caldwell's Between Two Worlds was published in 1992, while other books are on the way.

5) World Who's Who in Environment \& Conservation:- See 8 under the heading of PROJECTS ... .

6) Biosphere Day:- As indicated in 6 under the heading of PROJECTS ..., this will hopefully be supported soon by a Biosphere Fund, Biosphere Prizes, and a network of Biosphere Clubs which may yet span the world in the manner of Rotary or Lions Clubs, having an imperative raison-d' être.

7) Best Paper Prize:- This for 1991 was again divided four ways between Dr Rohana Ulluwishewa for her paper entitled 'Modernization versus Sustainability: Disintegrating Village Agro-ecocomplexes in the Dry Zone of Sri Lanka', Dr W. Douglass Shaw for his paper entitled 'Environmental Economics: Can Economics Help Mother Earth?', Professor Richard W. Butler for his paper entitled 'Tourism, Environment, and Sustainable Development', and Dr John Schelhas for his paper entitled 'A Methodology for Assessment of External Issues Facing National Parks, with an Application in Costa Rica'. Choice of the winners for these annual awards is solely by the Foundation's confidential Awards Committee to whom our warm thanks are due. Through the foresight and generosity of a member of the President's family, winners of a Best Paper Prize or part thereof will henceforth be presented with a signed certificate together with their cheque.

8) Human-caused Soil-ecological Changes and Their Effect on The Biosphere:- As already indicated above in FURTHER DESIDERATA (i), an aspect of this vast project was activated during the year through Russian-United States collaboration* and more is now hoped-for with WCMC, Cambridge, England.

9) Equable Use of the Biosphere's Commons is another theme for a needed book and action in addition to the three mentioned above as 7(c), 7(d), and 7(e).

10) World Collating Office of Environmental Education:- It is hoped that an effective International Environmental Education Council will emerge from an International Workshop on Environmental Education which was held in June 1992 in Rio de Janeiro, Brazil, during the United Nations Conference on Environment and Development. ${ }^{\dagger}$

11) Finally we wish good fortune to the enterprising 'Biosphere 2' experimenters near Tucson, Arizona, USA, whose two-years' period of rigorous incarceration is to end in September 1993, and recall remonstrating with two or three of them, during the Vernadsky jubilee events in Kiev and Moscow in 1988, ${ }^{* *}$ for calling their experiment 'the Biosphere' as if ours did not exist - hence presumably their adoption of the above name. We hope to be able to take up their invitation to visit the site and offer our comments following the 18-21 February 1994 Churchill, Manitoba, Symposium on Circumpolar Ecosystems in Winter, which we are to introduce and subsequently address on the subject of changes in the last 60 years.

Nicholas Polunin, President

Foundation for Environmental Conservation

7 Chemin Taverney (7th \& 8th Floors)

1218 Grand-Saconnex

Geneva, Switzerland. * See 'Revision of Map of Ecoregions of the World (1992-95)', by Professor Vladimir N. Bashkin \& Dr Robert G. Bailey, Environmental
Conservation, 20(1), pp. 75-6, 1993.

$\dagger$ See Environmental Conservation, 20(1), pp. 90-1, 1993.

** See Environmental Conservation, 15(2), pp. 187-9, 2 figs, 1988, and cf. 16(3), pp. 280-2, 3 figs, 1989. 